\title{
Response
}

\section{VICTIMS-BOth Sides: \\ A Tribute to James V. Allridge III (1962-2004) Bob Gaucher}

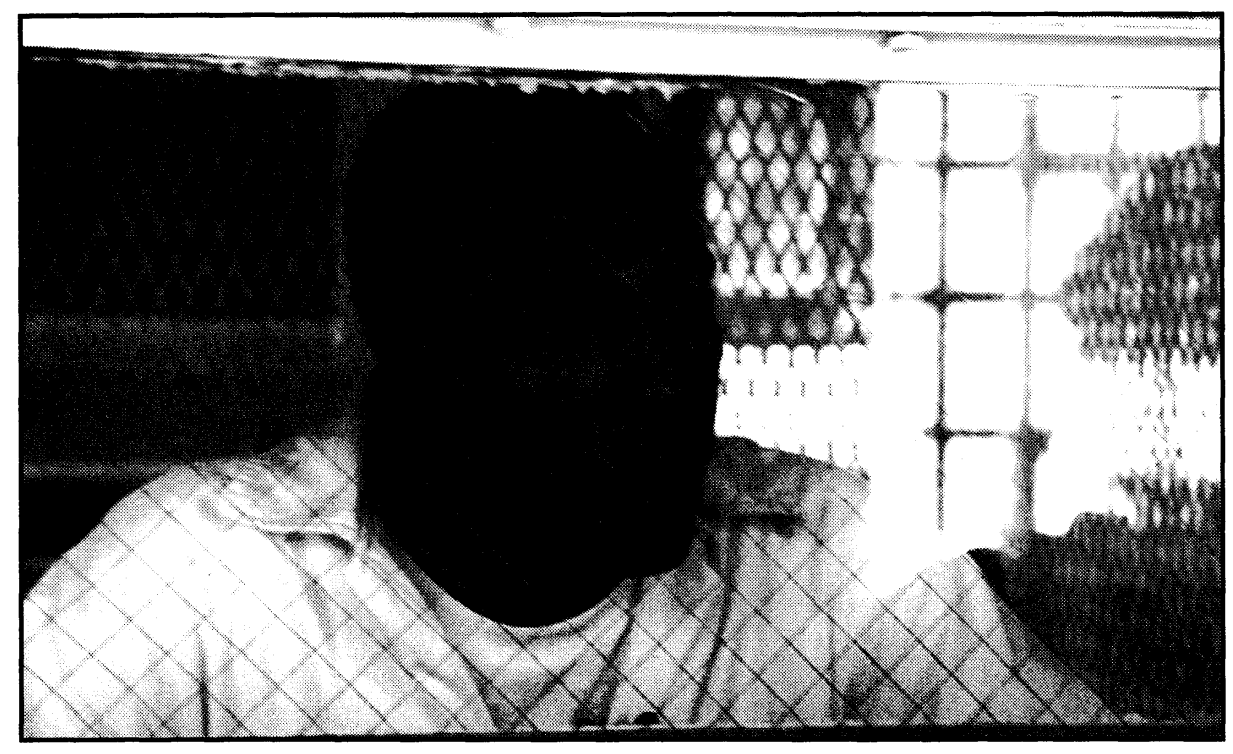

Tames Allridge entered my life with his correspondence of May 23, 1994. He included one of the handmade art cards he had been producing and two manuscripts, "Victims-Both Sides" and "Scum," which were subsequently published by the JPP in the spring of 1995 (volume 6:1). The artistic quality of the card directed me to inquire about his artwork, and as a result of our correspondence, volume 6:1 also featured his coloured drawing "Piano Wave" as cover art. Over the next decade James was a regular contributor to the journal. His drawings were featured on two additional covers ("Wolf Woman," 1997, vol. 8; and "In the Limelight," 2003, vol. 12). Three additional articles were also published. For years a framed copy of "Piano Wave" has hung in my office. It came to signify my relationship with James and the carceral cadence and rhythm of life on death row Texas that he shared with me. Over the ten years of our correspondence we became friends, and "talked" about life and death, and mostly, about art. 
James and Ronald Allridge were arrested on March 25, 1985 in Fort Worth, Texas for the shooting death of a convenience store clerk in a bungled robbery attempt. They were convicted on June 9, 1987, and sent to Texas' Death Row to await execution. James had been a high school honour student, and was working as a small businessman at the time of the homicide. He had no prior altercations with the law. In 1994 his execution date was scheduled for December 1, and he won a stay of execution in November of that year. The death chamber dominated 1995. James' execution was rescheduled for November 13, 1995, and his brother Ronald was executed June 8. On November 8, 1995, he received a stay of execution. By 2002 all avenues of appeal were essentially exhausted and he focused upon a petition for clemency. Two days before his scheduled execution date, the Texas Board of Pardons and Paroles voted 6-0 against recommending commutation. After spending 17 years on death row, James was executed on August 26, 2004.

In light of the execution of his brother Ronald in 1995, and the attrition of his friends and acquaintances to the death chamber, James remained amazingly optimistic and determined. His brother's death strengthened his resolve to spare his parents and family the torment and grief of a second execution (Allridge, $J P P, 1995$ a). His optimism was driven by his belief in the triumph of the human spirit and by his understanding that though he was responsible for a terrible mistake, he was also a redeemable human being and not industrial waste or "scum" (Allridge, JPP, 1995b). Over the next ten years James integrated his art and writing within a campaign against the death penalty and his own pending execution.

Despite the constraints of death row, he was able to develop his talents as an artist to a degree that amazed even him. While James had created art cards, note cards, and printed reproductions of his drawings, he was thrilled by the eventual recognition of his work as "art." Starting with the Prison Industrial Complex Art Show (organized by Carol Strick) in New York (2000), his drawings received growing international acclaim and were exhibited in Europe and North America. His "flower phase" work was particularly well received. The inclusion of "Crimson Dahlia" in another New York Art Exhibition (October 21-November 26, 2000) prompted this response:

I'm especially proud because this will be my first gallery exhibition. I have also been invited to participate in another exhibition in 
Germany, and one in Los Angeles, and two other people have contacted me about including my drawings in their book projects.

(Allridge, September 24, 2000)

"Lit Up Tulip" was included in the 5000 Flowers Project at the Fuller Lodge Art Center in Los Alamos, New Mexico (September 11-October 9, 2002). The exhibition of his art and discussion of his case in Orléans, France on June 14, 2002 is illustrative of the integration of his struggles and campaign against the death penalty with his art. This event was part of the Amnesty International Youth Program. The theme of the day was "Making Youngsters Sensitive to the Rights of People, Abolishment of the Death Penalty, and Racism."

With the help of his family and outside supporters, in 1998 James started producing printed cards of his coloured drawings to raise money to fund his ongoing appeals. The establishment of "Light Expressions" (and its website) in 2000 significantly extended his exposure as an artist. In 2002 and 2001, his coloured drawings were awarded first and second prizes in the Fortune Society Annual Prison Art Contests. Throughout 2003, and most of 2004, the "Light Expressions Tours" exhibited his work across Europe ("Expo James") and the United States.

James' identity became intertwined with his art and it was through his artwork that he sought to establish his social worth. The growing recognition of his artistry attested to his success. By exemplifying the humanity of death row prisoners and their ability to recognize their mistakes and selfrehabilitate, he sought to expose the pointless barbarity of the death penalty and therefore the need for clemency relief and abolition. The execution of his friend Napoleon Beazley, "who had grown and matured," was particularly pertinent to his campaign against the death penalty:

A continuing threat to society? Hardly. You would think the penal institution would have been applauding him and even take credit for rehabilitating him since that is supposed to be the purpose and function of the penal institution. But by executing him, they said that they had failed and that society had failed as well. It's a sad commentary on our times. (Allridge, June 16, 2002)

The successful development of James the artist and his campaign against the death penalty was greatly assisted by Beatrice Strobel, Christina Dodd, 
and their friends in Switzerland. In February 1994, with James' execution date scheduled, they created a registered charity "Fund For Life" to raise funds for legal assistance on his appeals. They provided support in many ways. By organizing exhibitions of his art, selling his art cards, and publicizing his plight in Europe, they rallied international opposition to his execution.

During times of heightened peril, their visits with James strengthened his spirit and resolve. The motto of the "Fund For Life Newsletter" captures the shared sensibility of James and his supporters:

A tree given the opportunity to live will grow,

Touch many lives, create beauty, give life - flourish.

Kill the tree and you create wood for coffins. Death.

Give life a chance. (FFL, January 1998, 1)

James also worked with abolitionist organizations such as the "Lamp of Hope Project" and the "Texas Coalition Against the Death Penalty." The support and public recognition he was able to draw together encouraged him to believe in himself, and fuelled his ability to struggle against his fate. His ability to reach out to us encouraged our opposition to the death penalty. James had an artist's sensibility that engulfed his relations with others and drew us to him. He understood our fears and concerns, and gently laid them aside:

Someone told me my art is too happy. Not what one would expect from a DR [death row] prisoner. Am I supposed to be showing pain through my art? What if I'm just happy and blessed to be alive no matter where I'm at? Shouldn't my art reflect that? So the written word can educate and say what my art does not. It is all a combined and unified effort. (Allridge, February 3, 2003)

A driving force of what he referred to as his "self-rehabilitation," was his concern for his parents and younger brothers. Having experienced the great torment and suffering of his family as a result of his brother's execution (see Allridge, 1997, JPP vol. 8:1) heightened his desire to prevent a repetition of their suffering and torment. His concern for family and friends led him to try to shield us from the depressing reality of his situation. His cheery 
optimism was put to good use in calming our fears as we rode the roller coaster of scheduled executions and reprieves. His own assessment of his art embodied this aspect of his character:

I now use dramatic contrasts of light and darkness to symbolize my hope that even in the darkest situations, beauty can still be found, if only we look towards the light. (Allridge, June 16, 2002)

In our correspondence James regularly expressed concern for his parents and the suffering he had put into their lives. He understood the depth of their continued traumatization and was acutely aware of their victimization by his terrible mistake, and the murderous response of the State of Texas. His optimism did not blind him to the most likely result of his struggles. Internationally, Texas represents the epitome of the hard-line penal philosophy, and is the leading state executioner in a country whose support for the death penalty is exceptional among Western nations. Impending executions were a constant in the carceral cadence of life on Death Row, Texas. "I'm sure you know that Texas recently executed 4 prisoners over 4 consecutive days, taking time off for the weekend, of course" (Allridge, December 15, 1995).

Though James' execution was not unexpected, the impact on his family and friends was devastating. In the fall of 2003 I was asked to write a submission in support of his petition for clemency. My quandary over how to appeal to the Texas Board of Pardons and Paroles prepared me for the worst. What type of people were they, and did they ever award clemency? What could one possibly say to move such people? In May 2004 he wrote and told me that his execution date had been set for August 26 and that only clemency stood between him and the death chamber. As the date drew near I experienced a rising sense of dread and despondency. These barbarians were really intent on killing my friend, and there was nothing I could do to stop this deliberate act of cold-blooded murder.

On August 24, 2004 the Texas Board of Pardons and Paroles rejected his clemency petition 6-0. James was executed August 26, 2004. During the week surrounding his execution I was immobilized, numbed by the enormity of the act of barbarism in which I had become enveloped. What was the impact on his aging parents? How much were they expected to endure? For nineteen years their lives have been tormented by fear and 
despair generated by state-sanctioned murder. What can possibly justify their continued victimization? What purpose did the execution of a James Allridge serve? This sensitive human being posed a threat to no one. And what of his loved ones and friends? What kind of society is willing to purposelessly victimize so many people?

After James' death I packed our years of correspondence, his cards, artwork, and newsletters, in a box. My participation in the second International Congress Against the Death Penalty, held in Montreal in November 2004, fuelled my sense of mourning and anger over his execution. It took me another six months to reopen that box and face the pain it contained. Rereading his letters and writing and viewing his artwork produced sadness, tears, and rage. Though grief-stricken by his pointless death I rediscovered his strength of character and spirit, and the beauty of his art. I rediscovered him as a voice for his fellow prisoners on Death Row, USA. Despite the predictable failure of his own struggle to survive, via his art, his campaign against the death penalty touched many people across the world. His accomplishments from a Death Row cell were remarkable and representative of the spirit of resistance of the imprisoned artist through the ages (Davis 1990; Franklin 1988, Gaucher 2002).

Michael Mac Giolla Ghunna in "Cultural Struggle and a Drama Project" $(J P P, 1996-97$, vol. 7:1) discusses the role of art and culture in the resistance of Republican political prisoners in the H Blocks of Northern Ireland:

It has become a defining feature of political prisoners throughout the world that they engage in cultural struggle. They write, compose poetry, sing and play music, paint, and carve. They utilize every form of self expression. They do so not merely because they are talented individuals... but because they wish to give voice to the pain of their people and articulate the need for radical change to end this pain. Indeed, Edward Said, the Palestinian academic, has termed this the role of the intellectual in society. Similarly, the recently executed Ken Saro-Wiwa described his role thus: "For a Nigerian writer in my position...literature has to be combative.... What is of interest to me is that my art should be able to alter the lives of a large number of people, of a whole community, of an entire country. ...It is serious, it is politics, it is economics, it's everything. And art in that instance becomes so meaningful...." (7) 
Despite the solitude and tight constraints of death row, and the constantly intruding threat of execution, James established himself as an artist, writer, and campaigner against the death penalty with a remarkable degree of success. Though his journey was tragic, and his death pointless, his life was not wasted. Many of us were enriched by our relationship with James, and so I will try to remember him in "peace and light," and be thankful that our paths crossed. Megwetch, James.

Bob Gaucher

August 5, 2005

\section{Bibliography}

Allridge III, James V. (1995a) "Victims-Both Sides," JPP vol. 6:1, 4-67.

_. (1995b) "Scum," JPP vol. 6:1, 68-69.

. (1997) "Commemorative Celebration in Honour of Ronald Keith Allridge,"

JPP vol. 8, 21-26.

- (1998) Fund For Life Newsletter, \#1.

. (2001) "Dispatches from Death Row," JPP vol. 11, 62-67.

. (2003) "From Where My Strength Cometh," JPP vol. 12, 86-88.

Cited correspondence with Bob Gaucher: December 15, 1995; September 24, 2000; June 16, 2002; February 3, 2003.

Davies, Ioan (1990) Writers in Prison, Toronto: Between the Lines.

Franklin, H. B. (1989) Prison Literature in America: The Victim as Criminal and Artist, New York: Oxford University Press.

Gaucher, Bob (ed.) (2002) Writing As Resistance: The Journal of Prisoners on Prisons Anthology (1988-2002), Toronto: CSPI.

Mac Giolla Ghunna, Michael (1996-97) “Cultural Struggle and a Drama Project," JPP, vol. 7:1,7-9. 